\title{
Edaphic and phytochemical factors as predictors of equine grass sickness cases in the UK
}

\section{Sarah E. Edwards, Kathrin E. Martz, Anja Rogge and Michael Heinrich*}

Centre for Pharmacognosy and Phytotherapy, The School of Pharmacy, University of London, London, UK

\section{Edited by:}

Ursula Gundert-Remy,

Arzneimittelkommission der deutschen

Ärzteschaft, Germany

\section{Reviewed by:}

Mosaad A. Abdel-Wahhab, National

Research Centre, Egypt

Daniel Dietrich, University of Konstanz,

Germany

\section{${ }^{*}$ Correspondence:}

Michael Heinrich, Centre for

Pharmacognosy and Phytotherapy, The

School of Pharmacy, University of

London, 29-39 Brunswick Square,

London WC1N 1AX, UK.

e-mail:michael.heinrich@pharmacy.

ac.uk
Background: Equine dysautonomia or equine grass sickness (EGS), as it is more commonly known, is a usually fatal disease of equids of uncertain etiology, although associated with grazing, that affects the autonomic and enteric nervous system. Lowered gastrointestinal motility, leading to paralysis of the gut, is one of the main symptoms of EGS. Previous studies have implicated anaerobic bacteria, notably Clostridium botulinum, but what triggers the severe bacterial infestations remains enigmatic. We hypothesized that a detailed comparison of soil mineral and botanical composition of EGS and control sites would yield new insights into the causation of the disease. Results: Between March 2007 and September 2008, soil, plant, and water samples from a total of 23 EGS sites and 11 control sites were studied. Metal and non-metal element levels of the soil and herbage samples were assessed. Significantly, EGS sites had higher levels of soil nitrogen, and significantly higher levels of iron, lead, arsenic, and chromium in the herbage. Toxic Ranunculus spp. (buttercups) were found in abundance at every EGS site, making ingestion plausible. Conversely, neurotoxin-producing cyanobacteria were not found in any of the water samples analyzed. Conclusions: The significantly higher levels of iron and heavy metals found in herbage growing in EGS sites, in addition to toxic Ranunculus species, suggest that previously unknown triggers are involved in a multi-factorial EGS etiology. Our results also show that cyanobacteria on the other hand, are unlikely to be a factor in EGS. Consequently, the concomitant presence of two (or more) factors could be the trigger for an outbreak of EGS.

Keywords: equine grass sickness, enteric nervous system, equids, heavy metals, iron, Ranunculus spp. (Ranunculaceae), cyanobacteria, UK

\section{INTRODUCTION}

Equine dysautonomia or "grass sickness" (EGS) is a distressing and usually fatal disease of equids of uncertain etiology (Collier et al., 2001). Symptoms include damage to the autonomic nervous system and lowered gastrointestinal motility, which in acute cases results in total ileus (Pirie, 2006). Histopathologically the disease is characterized by lesions in neurones of the autonomic and enteric nervous system (Cottrell et al., 1999; McCarthy et al., 2001; Hudson et al., 2002; Hilbe et al., 2005; Milne et al., 2005).

Equine grass sickness was first identified early in the 20th Century, following an outbreak amongst army horses stationed in NE Scotland (Tocher, 1924), and the following losses in the area were so severe, it is reputed to have accelerated the introduction of tractors (Milne and McGorum, 2006). EGS is most prevalent in Great Britain, although it has also been diagnosed across Northern Europe, and isolated cases have been reported from Australia and the Falkland Islands (Pirie, 2006). An apparently identical disease (known as "mal seco") is recognized in Patagonia and Southern Chile (Uzal et al., 1992; Uzal and Robles, 1997; Pirie, 2006).

Epidemiological evidence from the United Kingdom indicates that EGS is a non-contagious disease (Gilmour and Jolly, 1974), but linked to certain sites (Wood et al., 1998; McCarthy et al., 2004; Newton et al., 2004). It is seasonal (with most cases occurring between April and July); and likely to be caused by an unknown constituent in the horses' diet and/or environment (Wood et al.,
1998; Newton et al., 2004; French et al., 2005). As the name suggests, EGS is strongly associated with pasture, although there have been rare cases of the disease occurring in entirely stable-kept horses (McCarthy et al., 2001).

Increasing evidence suggests that the widely distributed bacterium Clostridium botulinum may be involved in EGS (Hunter et al., 1999; Poxton et al., 1999; Böhnel et al., 2003; McCarthy et al., 2004; Nunn et al., 2006) and microbiological studies have shown that anaerobic bacteria levels cultured from fecal and ileal samples were 10- to 100-fold greater in EGS cases as compared to controls (Garrett et al., 2002). It has been hypothesized that EGS is a toxico-infectious condition similar to infant botulism in humans, which may explain the different clinical and histopathological features of EGS and classic botulism in the horse (Hunter et al., 1999; Wood and McGorum, 1999; Collier et al., 2001; Böhnel et al., 2003; Newton et al., 2004).

A multi-factorial etiology has also been proposed (McCarthy et al., 2001, 2004), whereby one or more factors, either dietary (Hunter et al., 1999) or environmental (French et al., 2005), are likely to predispose the animals to opportunistic infection by bacteria, particularly clostridial bacteria, C. botulinum (Hunter et al., 1999; Poxton et al., 1999; Böhnel et al., 2003; McCarthy et al., 2004; Nunn et al., 2006) and C. perfringens (Ochoa et al., 1974; Ochoa and de Valendia, 1978), which have both been associated with EGS. 
Over recent years, in complex diseases scientists have adopted an approach called causal networks, or causal modeling, based on statistical evidence of composite mechanisms of multiple interactions of potential hazards or risk factors, with various dynamic features of the host and any pathogens involved, to describe disease occurrence (Thagard, 1999). These networks often arise from the inability to explain disease onset, or experimentally reproduce disease outbreak, with a single etiological agent. So while there is strong evidence for the role of a C. botulinum-like organism, the disease has not been reproduced by experimental challenges with this agent alone. Similarly, epidemiological studies have consistently associated disease outbreaks with particular pastures and in certain seasons, co-grazing animals may be unaffected, and adjacent pastures may never harbor an outbreak. It is clear that a network of potential causes and mechanisms for EGS is needed - and that this network would include pathogen and host characteristics, features of the environment, and management practices.

A causal network can be used to identify possible intervention points to develop a strategy for controlling, and potentially curing the disease. However, a complete network can only be developed with statistical evidence of each of the potential hazards, risk factors, as well as the various dynamic features of the host and any pathogens involved. In this study we aim to supplement the current body of research investigating clinical and epidemiological aspects of EGS (for examples see Wood et al., 1998; Cottrell et al., 1999; McCarthy et al., 2001, 2004; French et al., 2005; Pirie, 2006), with statistical data regarding hazards that could potentially explain some of the geographical and seasonal features of the disease, namely potential toxins that could contaminate the soil, forage, and other elements of the horses' diet.

The pasture association of EGS have led many to propose a potential role for toxins in the development of the disease (Tocher et al., 1923; Pool, 1928; Collier et al., 2001; Newton et al., 2004). Possible pasture based toxins include those originating from plants (e.g., ranunculin), soil (e.g., heavy metals), and microbes (e.g., cyanobacteria). Among the cyanobacteria (also known as blue-green algae), there are some that produce highly toxic secondary metabolites, the cyanotoxins, including the hepatotoxins nodularin and microcystin (MC, Codd et al., 2005) one of the most frequently found toxins in fresh water bodies (Chorus and Batram, 1999). A possible link between avian botulism and cyanobacterial blooms was investigated by Murphy et al. (2000), who proposed that the cyanotoxins MC and anatoxin-A put stress on the birds, thus making an outbreak of botulism more probable. Since strains of C. botulinum type $\mathrm{C}$ are responsible for large outbreaks of botulism in wild birds (Rocke, 2006), and have also been associated with EGS cases (Hunter et al., 1999), it was considered that an investigation into the potential link between EGS and cyanobacteria was warranted.

We hypothesized that herbage and soils from EGS outbreak sites contain statistically significant differences in the levels of toxins compared to herbage and soils from control sites, thereby providing a basis predicting which potential risk factors for the development of EGS in susceptible horses would be of particular importance.

\section{MATERIALS AND METHODS SAMPLING}

Obviously, the study required a responsive mode of sampling, and in order to achieve this, the project was advertised in specialized media, and via informal networks of horse owners. Sites were predominantly privately owned fields that were part of small-holdings or farms, but also included livery yards, a trekking center, and a horse rescue center. Horse/pony and pasture managers/owners were interviewed from each site and a questionnaire was used to record both case and site information, including pasture management practices. Anonymity of owners was assured. Data were held in a secure relational database at the School of Pharmacy, University of London, developed specifically to store information collected from EGS and control sites.

Between March 2007 and September 2008, twenty-three sites where there had been confirmed cases of EGS (in total representing $>90$ acute, sub-acute, or chronic cases), and 11 control sites, where, as far as was known, no EGS cases had ever occurred, were sampled throughout Great Britain from NE Scotland to the South coast in West Sussex. EGS sites were visited as soon as practically possible following contact from owners, so that length of time between cases occurring and investigation was minimized. Due to the necessarily responsive nature of this study, in practice this varied from a few days to a maximum of 3 years. Sites where the last EGS case had occurred $>3$ years before were excluded from the study. The number of cases that had occurred on an EGS site varied from 1 to over 20 (Table $\mathbf{1}$ ).

At each EGS site, a botanical survey was undertaken, using various publications (including Hubbard, 1984; Stace, 1997; Rose, 2006) to confirm identification of species in situ. In some cases, where full identification was uncertain, voucher specimens were collected for identification later in the herbarium.

One to three soil samples of between $500 \mathrm{~g}$ and $1 \mathrm{~kg}$ (taken from the top layer, just beneath herbage, c. $0-15 \mathrm{~cm}$ depth) were collected from each site (both EGS and control sites), at random intervals along a "W" shape. One to three herbage samples of between 300 and $500 \mathrm{~g}$ were also collected at random intervals along a "W" shape from paddocks where the equines with EGS had grazed, and from control sites. Ranunculus spp. (buttercups) were consistently found growing (usually in abundance) at each EGS site, and as these plants are known to contain a toxic, pro-inflammatory compound, voucher specimens and samples were collected for analysis. Where buttercups were found growing in control sites, these were also collected for comparison. Samples (both soil and plant) were placed in re-sealable freezer bags, clearly labeled, and held in cool boxes during transit to the laboratory, where they were then weighed and stored in freezers at $-20^{\circ} \mathrm{C}$.

Water samples were obtained between April 2007 and January 2008 from 16 different sites in England, Scotland, and Wales where confirmed EGS cases had occurred. Samples were collected from troughs, streams, and puddles where EGS horses/ponies were known to have drunk from (see Additional File 1 in Supplementary Material for details). They were collected in 100 and $250 \mathrm{ml}$ sterile glass bottle containers that were lowered into the water, filled, brought up again and closed. The samples were transported in iceboxes equipped with ice packs. After arriving at the laboratory they 
Table 1 | Site, number of cases and date of sample collection.

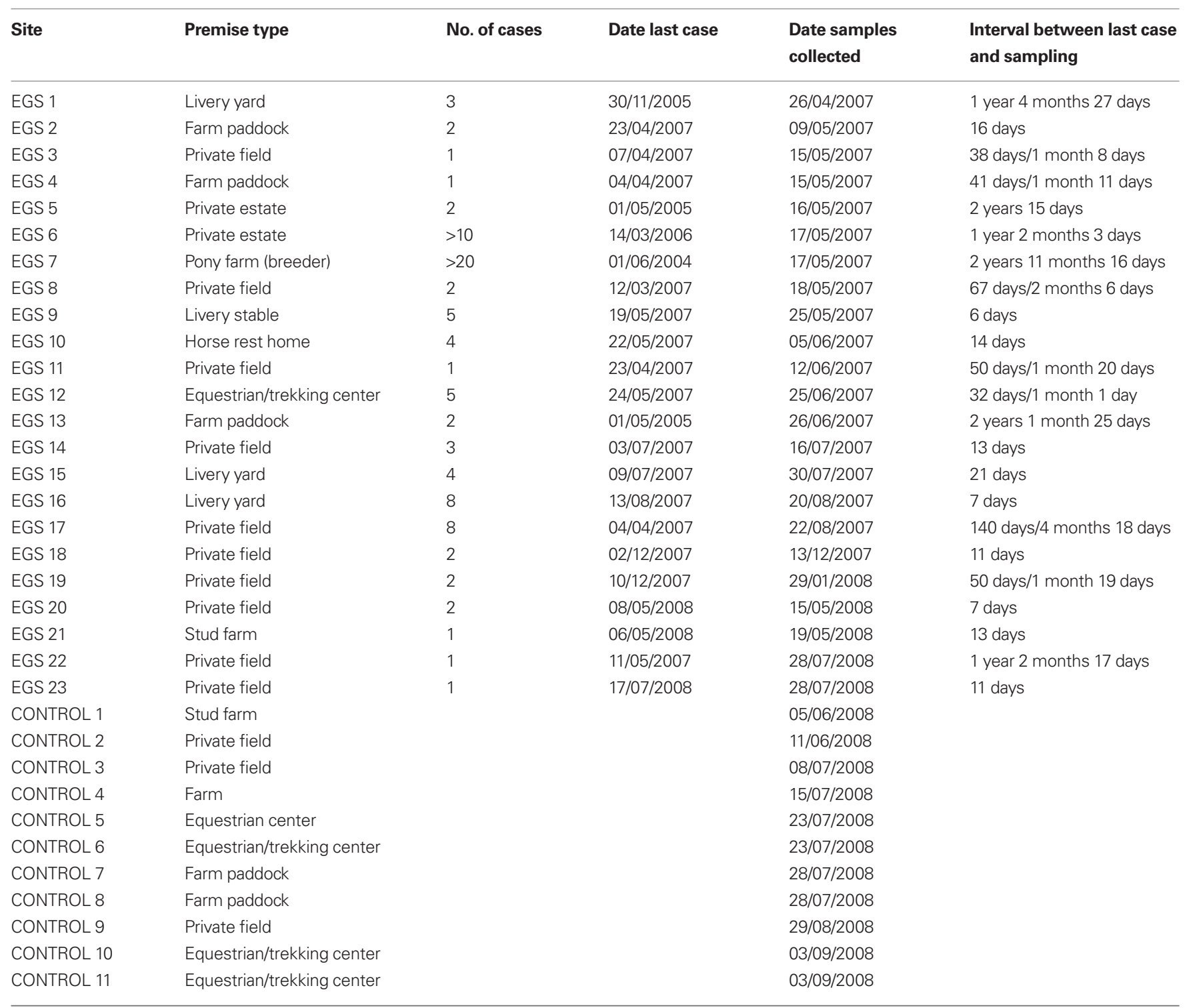

were frozen at $-20^{\circ} \mathrm{C}$ and stored until the investigation. A control sample was collected from a pond carrying visible phytoplankton on the water surface at the London Equestrian Centre on the 28th November 2007. No case of EGS has been reported from there.

\section{ANALYSIS OF SOIL AND HERBAGE SAMPLES}

Soil and herbage samples were sent to NRM Laboratories for metal and non-metal element analysis. Where more than one soil or herbage sample bag existed for a site, these were put together and treated as just one soil or herbage sample for analysis. Samples were digested in Aqua Regia by microwave digestion, using a documented in-house method, based on recommended protocols from the microwave instrument manufacturer (CEM Instruments, USA). Diluted Aqua Regia extracts were analyzed for mercury using documented in-house atomic fluorescence method, based on recommended protocols supplied by the instrument manufacturer (PS Analytical Ltd, UK); and for other elements (Al, As, Cd, Cr, Cu,
Fe, Mo, Ni, Pb, P, K, Mg, Ca, Mn, B) using a documented in-house ICP-OES method based on recommended protocols from the instrument manufacturer (Perkin Elmer LAS Ltd, UK). The following were analyzed using an in-house method based on MAFF RB427 (Ministry of Agriculture, Fisheries and Food, 1986): pH, available magnesium, available potassium, available phosphorus, mineral nitrogen, nitrate, and ammonia. Sample analyses of total nitrogen and sulfur were undertaken using a documented in-house Dumas method, based on recommended protocols from the instrument manufacturer (Thermo Fisher Scientific, USA). DTPA extraction for iron was undertaken using an in-house method based on Liang and Karamanos (1993).

\section{Statistical Analysis of Soil and Herbage Content}

The two sample $t$-test assuming non-equal variances was undertaken using Microsoft Excel, looking at soil and herbage metal and non-metal element levels, to test the null hypothesis that both EGS 
and control sites come from the same population. An alternative non-parametric statistical method was also employed, namely the Mann-Whitney $U$ test, using SPSS statistical software, since it does not assume a normal distribution and is therefore much less likely than the $t$-test to give spuriously significant results due to one or two outliers (i.e., a type I error). The confidence level was set at $95 \%$ with $p<0.05$.

\section{ANALYSIS OF WATER SAMPLES Microscopic investigations}

To immobilize the water samples, $100 \mu \mathrm{l}$ of each sample was applied to an objective slide, frozen at $-70^{\circ} \mathrm{C}$ and freeze-dried. With the addition of $1 \%$ glycerol solution, a permanent sample was obtained. The samples were covered with a cover glass. The slides were then investigated at $40 \times$ and $100 \times$ magnification with an ordinary light microscope. The samples were examined for any cells that could possibly be algae or cyanobacteria, and the detected structures described. Structures were classified according to the forms of the cells as: unicellular or multicellular, filamentous or round shaped, round to elongate; mucilage, pigment accumulation.

Cellular findings were investigated further by using a green filter to detect fluorescence. As reference, slides with Anabaena and Synechocystis 6803 were prepared and compared to the water samples concerning size, color, and shape.

\section{Methods for measuring microcystin}

Enzyme-linked immunosorbent assay test. The enzyme-linked immunosorbent assay (ELISA) Test ("Congener-Independent Immunoassay", Alexis Biochemicals ${ }^{\circledast}$ ) detects $\mathrm{MC}$ and nodularin in an indirect manner. The kit was developed to fit the demands of a routine analytical program for raw and drinking water. The test principle is based on an indirect competitive reaction of antibodies against the amino-acid ADDA-substructure of MCs (MC-LR, -RR, -YR, -LW, -LF, 3-desmethyl-MC-LR, 3-desmethylMC-RR), and nodularins. The detection limits are between 0.02 and $0.07 \mathrm{ng} / \mathrm{ml}$, depending on the variants measured, allowing detection of MCs well below the WHO guideline for drinking water $(1.0 \mathrm{ng} / \mathrm{ml})$. Given the low detection limit, sample analyses without pre-concentration are possible (Fischer et al., 2001) In order to release the toxin, the samples were freeze-thawed and sonicated for $1 \mathrm{~min}$ in an ultrasonication bath. The procedure was repeated twice. The water samples were centrifuged for $15 \mathrm{~min}$. The supernatant was filtered through a PVDF-syringe filter $(0.45 \mu \mathrm{m})$, which has low protein-binding capacities. Fifty microliters of the filtrate was applied to the coated well plate, and the ELISA test undertaken as written in the manufacturer's descriptions. MC standards were carried along with each assay run (Fischer et al., 2001).

Validation. In order to investigate if the sample preparation and handling was done correctly, water from the control site was spiked with the standard substances provided by the ELISA kit. Hundred microliters of each standard was mixed with $100 \mu \mathrm{l}$ of the water and the same procedure followed as described above (Fischer et al., 2001), excluding the centrifugation step. The spiked sample from the control site was not centrifuged to be able to detect any matrix effects from substances that were not removed after the filtration step. However, there was no such effect detectable. With each run of the assay with the samples, two spiked samples from the control site with different concentrations were carried along to validate the test. These control samples were handled in the same way as the samples obtained from EGS sites.

\section{QUANTITATIVE ANALYSIS OF RANUNCULUS SAMPLES}

Ranunculus samples from 17 EGS sites and one control site (the London Equestrian Centre) were analyzed for levels of ranunculin, which is hydrolyzed upon mastication to produce protoanemonin, a toxic lactone that is a known blistering agent and gastrointestinal irritant (Spoerke and Smolinske, 1990).

\section{Extraction}

The extraction method used was adapted from the one developed by Bai et al. (1996). Briefly, the frozen, lyophilized and ground plant material (aerial parts) was packed in a $2.5-\mathrm{cm}$ diameter glass column and extracted with methanol. The methanol was then evaporated and the residue partitioned between $20 \mathrm{ml}$ of chloroform and $20 \mathrm{ml}$ of $\mathrm{H}_{2} \mathrm{O}$. The aqueous fraction was washed several times with $20 \mathrm{ml}$ of chloroform and then filled up to $25 \mathrm{ml}$ with $\mathrm{H}_{2} \mathrm{O}$. The resulting extract was kept in a fridge at $4^{\circ} \mathrm{C}$.

\section{HPLC analysis}

Quantification was achieved by HPLC with pure ranunculin, obtained from Prof. em. Dr. Michael H. Benn, University of Calgary, Canada, as external standard. The authenticity of ranunculin was checked using NMR (Bruker Avance $400 \mathrm{MHz}$, solvent MeOD, data not shown).

Twenty-one milligrams of ranunculin were dissolved in $20 \mathrm{ml}$ of $\mathrm{H}_{2} \mathrm{O}$ and used as a reference (standard 1 - concentration $=1.05 \mathrm{mg}$ / $\mathrm{ml}$ ). This standard solution was stored in the fridge at $4^{\circ} \mathrm{C}$ for $1 \mathrm{month}$ and used later for HPLC. Another $25.4 \mathrm{mg}$ of ranunculin were dissolved in $25 \mathrm{ml}$ of $\mathrm{H}_{2} \mathrm{O}$ and used as a second reference (standard $2-$ concentration $=1.016 \mathrm{mg} / \mathrm{ml}$ ). This reference was made immediately prior to performing HPLC. Calibration curves were established for HPLC analysis using the following concentration series:
Standard 1:
$1.05 \mathrm{mg} / \mathrm{ml}$
$0.7875 \mathrm{mg} / \mathrm{ml}$
$0.525 \mathrm{mg} / \mathrm{ml}$
$0.2625 \mathrm{mg} / \mathrm{ml}$
Standard 2:
$1.016 \mathrm{mg} / \mathrm{ml}$
$0.762 \mathrm{mg} / \mathrm{ml}$
$0.508 \mathrm{mg} / \mathrm{ml}$
$0.254 \mathrm{mg} / \mathrm{ml}$

The calibration curves with a coefficient of determination of 0.9997 and 0.9995 were used to calculate the ranunculin concentration as the linear coherence was very high, so that the error terms were almost 0 . The regression line fits the data. Since ranunculin tends to eliminate glucose following no calculable scheme, it was necessary to use the sum of ranunculin and the aglycon to get representative results (see Additional File 2 in Supplementary Material for the areas corresponding to the concentration series obtained from HPLC for standards 1 and 2). 
The samples were analyzed at $210.3 \mathrm{~nm}$ (the detection wavelength) on a Waters 600 system (Controller, Waters 717 plus Autosampler, Waters 996 Photodiode Array Detector) with Empower Pro. The analytical column was a LiChroCART ${ }^{\circledast} 250-4$, LiChrospher ${ }^{\otimes} 100 \mathrm{NH}_{2}(10 \mu \mathrm{m}$, Merck, Darmstadt, Germany), the guard column a LiChroCART ${ }^{\circledast} 4-4$, LiChrospher $^{\circledast} 100 \mathrm{NH}_{2}(5 \mu \mathrm{m}$, Merck, Darmstadt, Germany). Each sample was analyzed in triplicate using acetonitrile $-\mathrm{H}_{2} \mathrm{O}(9: 1)$ as a mobile phase. The flow rate was $2.0 \mathrm{ml} / \mathrm{min}$ and the injection volume $40 \mu \mathrm{l}$.

\section{Statistical Analysis of Ranunculin Content}

Ranunculin content of Ranunculus samples from EGS sites was compared with control site samples using the two sample $t$-test assuming non-equal variances, with the confidence level set at 95\% (i.e., $p<0.05)$.

\section{RESULTS}

\section{EDAPHIC AND HERBAGE METAL AND NON-METAL ELEMENT LEVELS}

Soil and herbage samples from 23 EGS sites (see Table 2 for mean and range of number of EGS cases; case details can be found in Additional File 3 in Supplementary Material) and 11 control sites ( 0 cases) were analyzed for levels of metals and non-metal elements. Additional site details can be found in Additional File 4 in Supplementary Material. See Additional File 5 in Supplementary Material for the detailed results of metal/non-metal element levels used to perform statistical analyses. Locations of sites are shown in Figure 1.

Compared to control sites, EGS sites had significantly $(p<0.05)$ different levels of iron, lead, arsenic, chromium, and mercury in the herbage. While iron, lead, arsenic, and chromium were elevated in samples from EGS sites (see Figures $\mathbf{2}$ and $\mathbf{3}$ ), the converse was true of mercury. Significant difference was demonstrated using both the $t$-test and Mann-Whitney test for iron, lead, chromium, and mercury, strongly supporting these results; but only the $t$-test showed significance for arsenic.

Near significance was demonstrated using the Mann-Whitney $U$ test for both aluminum and nitrate nitrogen (see Figure 2), and the lack of significance at the $95 \%$ level in these cases may be attributed to a type II error due to small sample size. Significant/near significant results for herbage are shown in Table 3.

There was no statistically significant difference between EGS and control herbage samples in levels of the other metals and non-metals measured (i.e., phosphorus, calcium, magnesium, potassium, sulfur, manganese, copper, zinc, boron, nickel, and cadmium), using either the $t$-test or Mann-Whitney $U$ test. Figures demonstrating means and standard errors of element levels found in herbage samples from EGS sites compared to controls are shown in Additional File 6 in Supplementary Material.

There were significantly $(p<0.05)$ higher levels of both ammonium nitrogen levels and total nitrogen (i.e., nitrate nitrogen plus ammonium nitrogen) in soil samples collected from EGS sites in comparison with control sites using the $t$-test (see Figure 4), but there was no significant difference for $\mathrm{pH}$ or other soil metals and non-metals statistically analyzed using this method. The Mann-Whitney $U$ test showed no significant statistical difference between EGS sites and control sites with any of the soil sample analyses. Figures demonstrating means
Table 2 | EGS case statistics.

\section{No. EGS cases per site}

\section{Mean}

3.913043478

Standard error

0.899962765

Median

2

Mode

2

Standard deviation

4.316069798

Sample variance

18.6284585

Kurtosis

8.495940372

Skewness

2.68040656

Range

19

Minimum

1

Maximum

20

Sum

Count

90

23

Confidence level (95.0\%)

and standard errors of element levels found in soil samples from EGS sites compared to controls are shown in Additional File 7 in Supplementary Material.

\section{POTENTIAL BOTANICAL FACTORS}

Toxic plant species were found at every EGS site visited. Ranunculus spp. (buttercups) were the only toxic plants found at all 23 EGS sites visited in this study (and at 9 of 11 control sites), and, therefore, these samples were investigated further phytochemically (see below). Senecio jacobaea (ragwort) was found on 12 of the EGS sites (and on none of the control sites). Ragwort is well known for its deleterious effect on horses, due to the hepatotoxic pyrrolizidine alkaloids (Craig et al., 1991). Other toxic species found at some of the EGS sites included: Pteridium spp. (bracken) and Equisetum pratense (horsetail), which both contain thiaminase, an enzyme that destroys thiamine (vitamin B1), resulting in a neurotoxic syndrome (Evans, 1976); Rumex spp. (dock species), which contain oxalates that bind to calcium, thus causing hypocalcaemia (Panciera et al., 1990); Vicia sativa (common vetch), which contains a neurotoxin that may be responsible for lathyrism observed in humans (Ressler, 1962); and Digitalis purpurea (foxglove), which contains cardiac glycosides (Cooper and Johnson, 1984).

Potential toxic grass species found growing in EGS sites included Lolium perenne (perennial ryegrass), which contains alkaloids including peroline, that is mildly toxic to mice and may cause facial eczema in cattle that ingest it, and may be considerably more toxic if infected with particular species of endophytic fungi (Duke, 1983).L. perenne is also a known facultative metallophyte, and accumulates metals in its tissues (Bidar et al., 2007). Agropyron repens (couch grass), also found in EGS sites, produces agropyrene, a broadspectrum antibiotic and fungicide (Newell et al., 1996), and other allelopathic compounds including the flavonoid tricin (Friebe et al., 1995) and is a known heavy metal accumulator (Brej, 1998).

\section{RANUNCULUS SPP.: TOTAL RANUNCULIN CONTENT}

Ranunculus spp. (buttercups), found at all 23 EGS sites, were abundant in the majority of these, making (accidental) ingestion by horses highly plausible. Horses were observed grazing amongst 


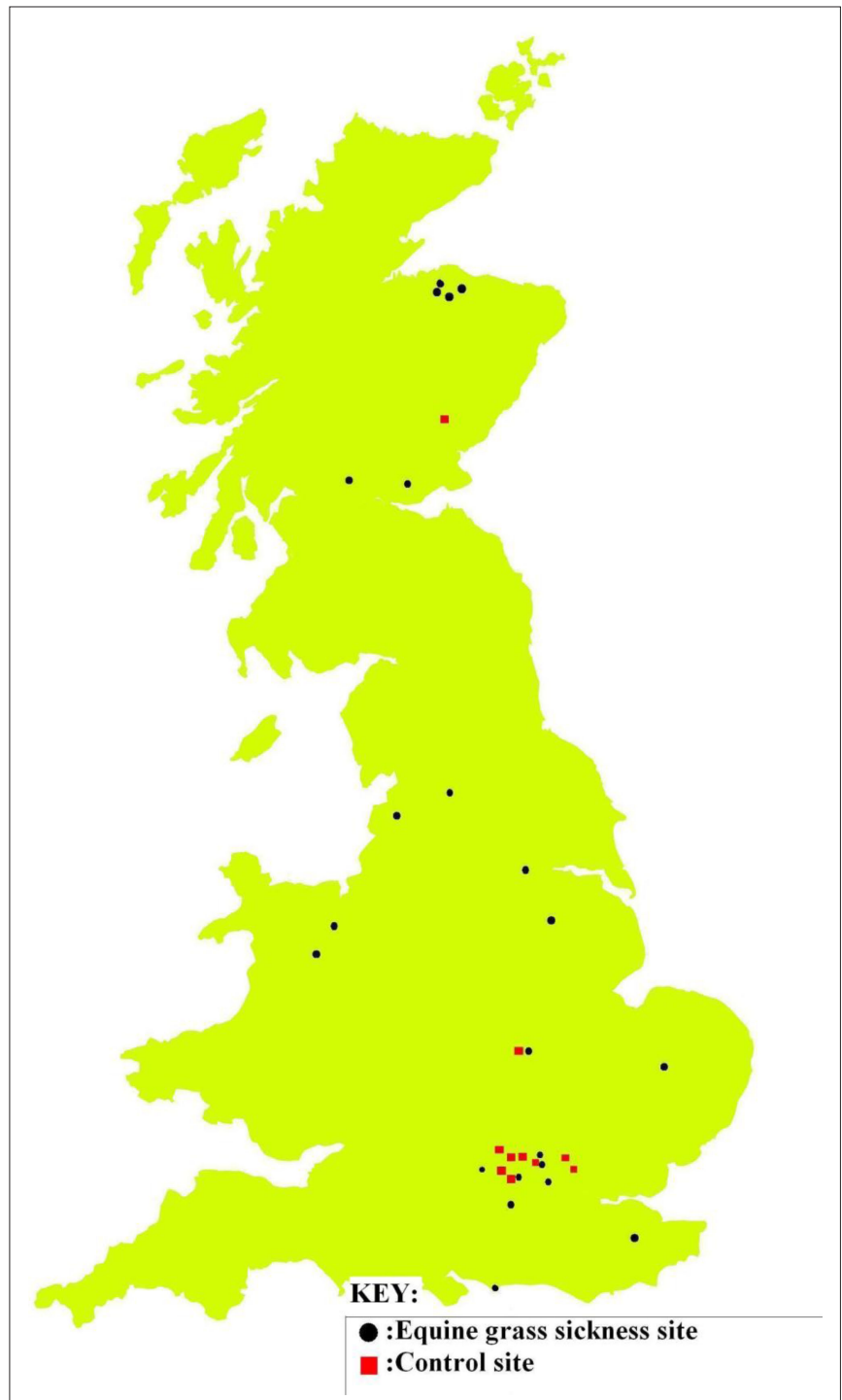

FIGURE 1 | EGS and control site locations. EGS (black/circle) and control (red/square) sites where samples collected.

Ranunculus plants at some of the sites during sampling, and a few horse owners had reported blistering or photosensitization on the muzzles of their animals, which could indicate contact with these plants (Prieto et al., 2003). The main species found was Ranunculus repens, although $R$. bulbosus and $R$. acris were also found on some of the sites. Analysis of extracts with HPLC showed considerable variation in the content of ranunculin. Compared to controls, samples from nine EGS sites had elevated levels of ranunculin, five of which had levels double that found in control samples, but others had lower levels (see Figure 5). However, the $t$-test demonstrated that overall significantly higher levels of ranunculin $(p<0.05)$ were found in the EGS samples compared with controls (see Additional File 8 in Supplementary Material for summary data and statistics). Figure 6 shows mean ranunculin levels of EGS site samples compared to controls.

\section{WATER SAMPLE ANALYSIS, CYANOBACTERIA}

Samples collected from EGS site water sources, including local streams or troughs (some of which exhibited algal blooms), were investigated for presence of cyanobacteria and the cyanobacterial toxin, MC. Initially, samples were studied under a light microscope and compared to cell samples from Anabaena and Synechocystis 6803. Several methods were assessed (including pigment analysis with spectrophotometry and thin layer chromatography), but did not allow the detection of any cyanobacteria constituents). An ELISA was used to measure presence of MC, validated using spiked samples, and none was detected in any of the samples tested (EGS2-3, EGS5-16, EGS18-19), i.e., the concentration was below the detection limit of $0.1 \mathrm{ng} / \mathrm{ml}$.

\section{DISCUSSION}

The potential involvement of hitherto poorly known environmental agents in the causation of EGS has initially been based on clinical observations and epidemiological studies that have demonstrated seasonal, geographical, and pasture-related correlations with the disease (Wylie and Proudman, 2009). However, the specific factors responsible had previously not been identified. The relatively low annual number of cases and reliance on owner-based case reporting after horses have fallen ill also complicate study design and realization. The aim of this study was to compare levels of potential environmental toxins between premises with confirmed cases of EGS and control sites in which no cases had been reported. The data from the sites examined demonstrate statistically significant differences between levels of iron and some heavy metals (lead, mercury, and chromium) in herbage collected from EGS sites in comparison to control sites. In addition, statistically significant differences in levels of potential nitrogenous and botanical toxins between EGS and non-EGS premises were also observed.

Heavy metals are well known as being deleterious to health and neurotoxic (Carpenter, 1994; Järup, 2003). Exposure to lead also induces oxidative stress through production of reactive oxygen species (ROS, Hsu and Guo, 2002). Acceptable upper limits are set in food for human consumption by regulatory bodies, including the European Commission and UK Food Standards Agency. For lead, this upper limit depends on food type, and varies between $0.1 \mathrm{mg} / \mathrm{kg}$ (in vegetables) and $1.5 \mathrm{mg} / \mathrm{kg}$ (in bivalves) (EC Commission, 2006). Lead levels in herbage at 12 of the EGS sites, but only two of the control sites, exceeded $1.5 \mathrm{mg} / \mathrm{kg}$. All (both EGS and control) herbage samples exceeded the upper limit set for cereals of $0.2 \mathrm{mg} / \mathrm{kg}$. The higher lead levels in herbage from EGS sites may have implication for any livestock grazed on it that are for human consumption. Based on an average horse $(500 \mathrm{~kg}$ ) consuming $11.5 \mathrm{~kg}$ of pasture dry matter per day, with a dry matter mean of $21 \%$ and lead level mean of $3.94 \mathrm{mg} / \mathrm{kg}$ in herbage from EGS sites, horses on these sites would consume about $216 \mathrm{mg}$ of lead per day. The fatal dose for horses is $2.4 \mathrm{mg} \mathrm{Pb} / \mathrm{kg}$ body weight/ day (Palacios et al., 2002). Also, the near significant finding of elevated aluminum levels in herbage from EGS sites compared with control sites is interesting, since aluminum has been shown to have a pro-oxidant effect and to act as a neurotoxin (Nehru and Anand, 2005). 


\section{Herbage Total Iron and Nitrate Nitrogen}

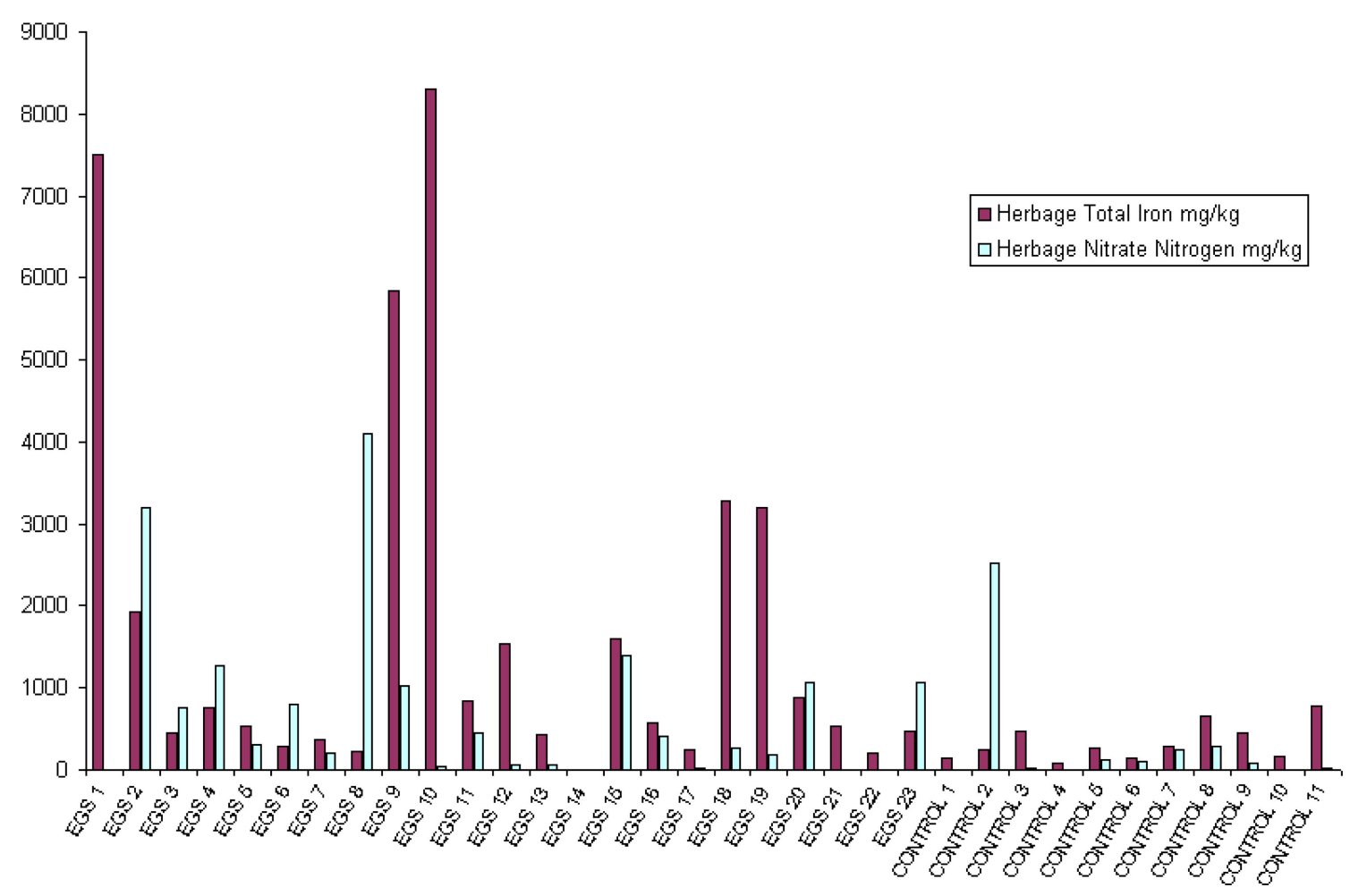

FIGURE 2 | Herbage total iron and nitrate nitrogen. Herbage total iron and nitrate nitrogen (mg/kg) per site (EGS and controls).

While levels of mercury were significantly higher in control sites compared to EGS sites, levels were low $(<0.1 \mathrm{mg} / \mathrm{kg})$ in all but two sites sampled, and therefore unlikely to be implicated as either an etiological or protective factor for EGS.

Horses on EGS sites are likely to be subjected to iron overload. Since iron acts as a pro-oxidant, releasing free radicals it contributes to oxidative stress and cellular damage, and impairs immune function (Walker Jr. and Walker, 2000; Valko et al., 2005). Iron loading has been implicated as a risk factor in sudden infant death syndrome of humans, also associated with pathogenic bacteria, including $C$. botulinum and C. perfringens (Weinberg, 2001), the same bacteria associated with EGS. Where post-mortem results were available from horse owners in this study, these indicated presence of pathogenic clostridial bacteria in the horses that died from EGS. Another study looking at gastrointestinal effects of oral administration of ferrous sulfate on rats demonstrated histopathological lesions and increase in fecal C. perfringens toxin after treatment with a high dose of $\mathrm{FeSO}_{4}$, and strong impact on fecal flora after $\mathrm{FeSO}_{4}$ was administered repeatedly at lower doses (Benoni et al., 1993).

Although it is commonly known that excess iron in the diet can cause constipation in humans (for example it is a common side-effect of iron supplementation routinely prescribed in pregnancy; Paesano et al., 2009), there have been surprisingly few studies specifically investigating the impact of iron on mammalian gastrointestinal motility (e.g., De Ponti et al., 1991; Nasu et al., 2001).
The higher levels of heavy metals found in herbage from EGS sites may inhibit gastrointestinal motility. Studies in isolated guineapig ileum have demonstrated that heavy metal ions such as cadmium and lead inhibit $\mathrm{K}^{+}$-induced contraction to an even greater degree that ferric or ferrous iron (Nasu et al., 2001). Inhibition of gastrointestinal motility could potentially result in an increase in anaerobic bacterial levels in the gut (Garrett et al., 2002).

The near significant higher levels of nitrate observed in EGS pasture is also compatible with possible involvement in EGS etiology. It has been demonstrated in humans that nitrates decrease autonomic nervous activity, leading to inhibition of gastrointestinal motility (Nomura et al., 2004). It has also been shown that gastrointestinal bacteria generate nitric oxide (NO) from nitrate and nitrite (Sobko et al., 2005), and NO is a key signaling molecule involved in regulation of gut motility (Stanek et al., 2008).

It is known that decreased gastrointestinal motility in EGS cases can be partly accounted for by degeneration of cholinergic neurones in enteric plexi, with the resulting reduction in release of acetylcholine neurotransmitter (John et al., 2000) and free radical generation leading to neuronal death (Götz et al., 1994). Herbage from EGS sites had reduced antioxidant and weak pro-oxidant activities compared with controls (McGorum et al., 2000). Horses suffering from EGS had altered levels of several antioxidants, consistent with oxidative stress. While levels of some antioxidants were lower in EGS sites, vitamin Clevels were elevated (McGorum et al., 


\section{Herbage Total Arsenic, Chromium and Lead}

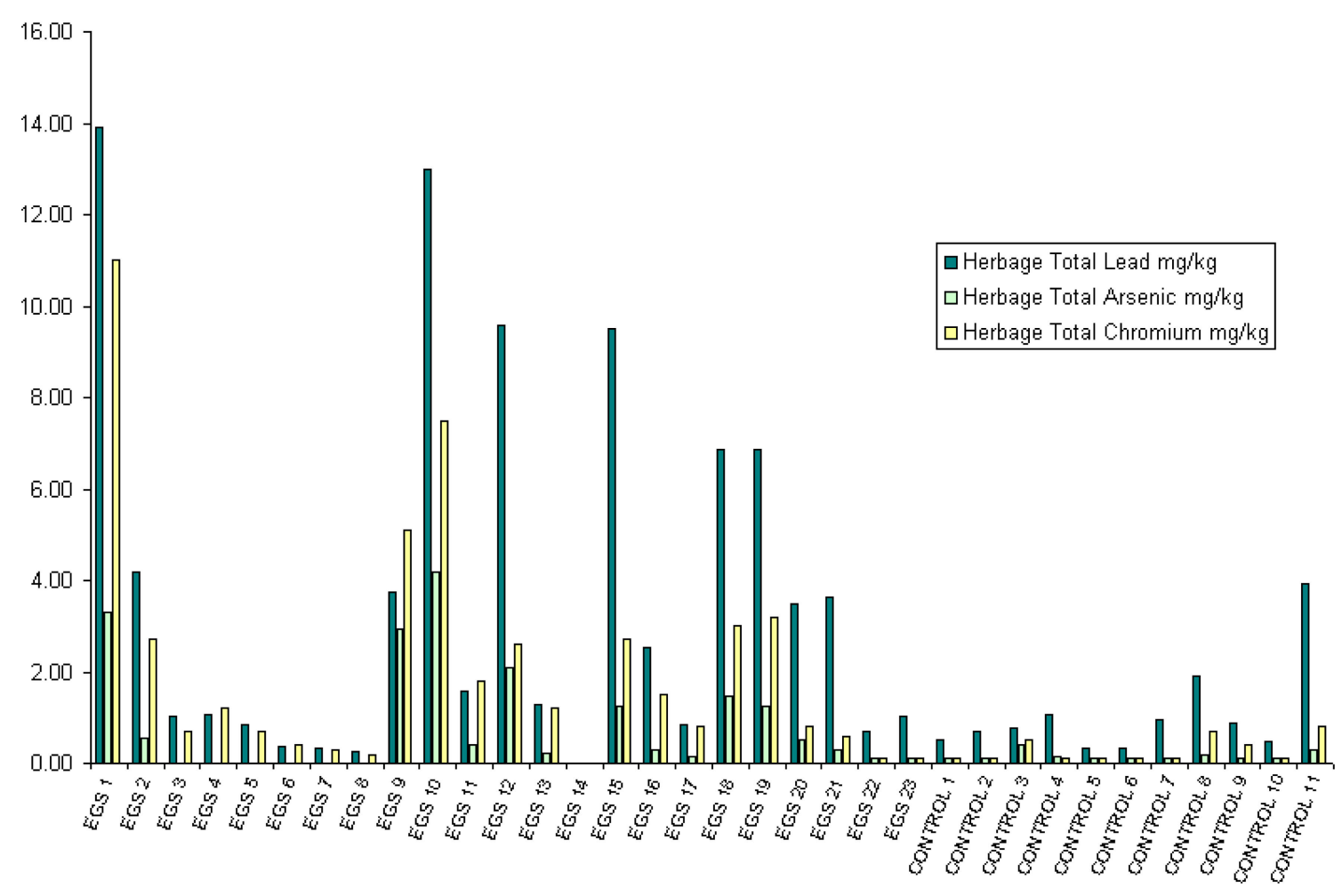

FIGURE 3 | Herbage total arsenic, chromium, and lead. Herbage total arsenic, chromium, and lead (mg/kg) per site (EGS and controls).

Table 3 | Herbage significant differences between EGS and control sites. Significance $(95 \%$ confidence level/p $<0.05) /$ near significance between EGS and control herbage samples were found for the following analyses of element levels.

\begin{tabular}{lllllllll}
\hline Element & $\begin{array}{l}\boldsymbol{t} \text {-Test } \\
(\boldsymbol{p} \text {-value) }\end{array}$ & $\begin{array}{l}\text { Mann-Whitney } \\
\text { test }(\boldsymbol{p} \text {-value })\end{array}$ & $\begin{array}{l}\text { EGS mean } \\
(\mathbf{m g} / \mathbf{k g})\end{array}$ & $\begin{array}{l}\text { EGS standard } \\
\text { deviation }\end{array}$ & $\begin{array}{l}\text { EGS } \\
\text { range }\end{array}$ & $\begin{array}{l}\text { Control mean } \\
(\mathbf{m g} / \mathbf{k g})\end{array}$ & $\begin{array}{l}\text { Control standard } \\
\text { deviation }\end{array}$ & $\begin{array}{l}\text { Control } \\
\text { range }\end{array}$ \\
\hline $\mathrm{As}$ & 0.006 & Not sig. & 0.87 & 1.22 & 4.19 & 0.16 & 0.10 & 0.31 \\
$\mathrm{Al}$ & Not sig. & $0.062^{*}$ & 691 & 675.5 & 1569 & 197 & 188.64 \\
$\mathrm{Cr}$ & 0.002 & $<0.001$ & 2.19 & 2.67 & 10.9 & 0.28 & 0.271 \\
$\mathrm{Fe}$ & 0.004 & 0.002 & 1818 & 2391.51 & 8102 & 330 & 224.54 \\
$\mathrm{~Pb}$ & 0.003 & 0.026 & 3.94 & 4.2 & 13.65 & 1.08 & 1.05 \\
$\mathrm{Hg}$ & 0.004 & $<0.001$ & 0.038 & 0.04 & 0.19 & 0.068 & 0.7 & 3.117 \\
Nitrate N & Not sig. & $0.063^{*}$ & 759 & 1049.26 & 4096.9 & 310 & 738.75 \\
\hline
\end{tabular}

${ }^{*}$ Near significance at the 95\% confidence level.

2003), which is of interest, since vitamin $C$ is required for iron absorption (Hallberg et al., 1989). Consequently, iron may be partly responsible for the histopathology observed in EGS cases. As far as is known, no studies have measured iron or lead concentrations in histopathologic sections of the enteric plexi (or peripheral tissues) in EGS versus control cases, a topic that requires veterinary investigation. However, impacted ingesta in the horse gastrointestinal tract of EGS cases are typically black-coated (Hudson and Pirie, 2005), and analysis of serum from EGS cases have demonstrated elevated levels of bilirubin (Marrs et al., 2001) which could indicate excessive ingestion of iron in the diet. Freely available iron (such as in fully saturated transferrin or free hemoglobin) will also greatly enhance bacterial virulence (Weinberg, 1999; Bullen et al., 2005).

Daily pasture intakes of horses are variable, influenced by abundance, structure, quality of plant resources, and individual preferences (Edouard et al., 2008). It is estimated that a horse consumes between 1.5 to $3.1 \%$ of its body weight in pasture dry matter per 24-h period (Dowler and Siciliano, 2009). Based on an average $500 \mathrm{~kg}$ horse grazing out $24 \mathrm{~h}$ per day, the horse will consume between 7.5 and $15.5 \mathrm{~kg}$ dry matter from pasture per day. With a 


\section{Soil Nitrogen}

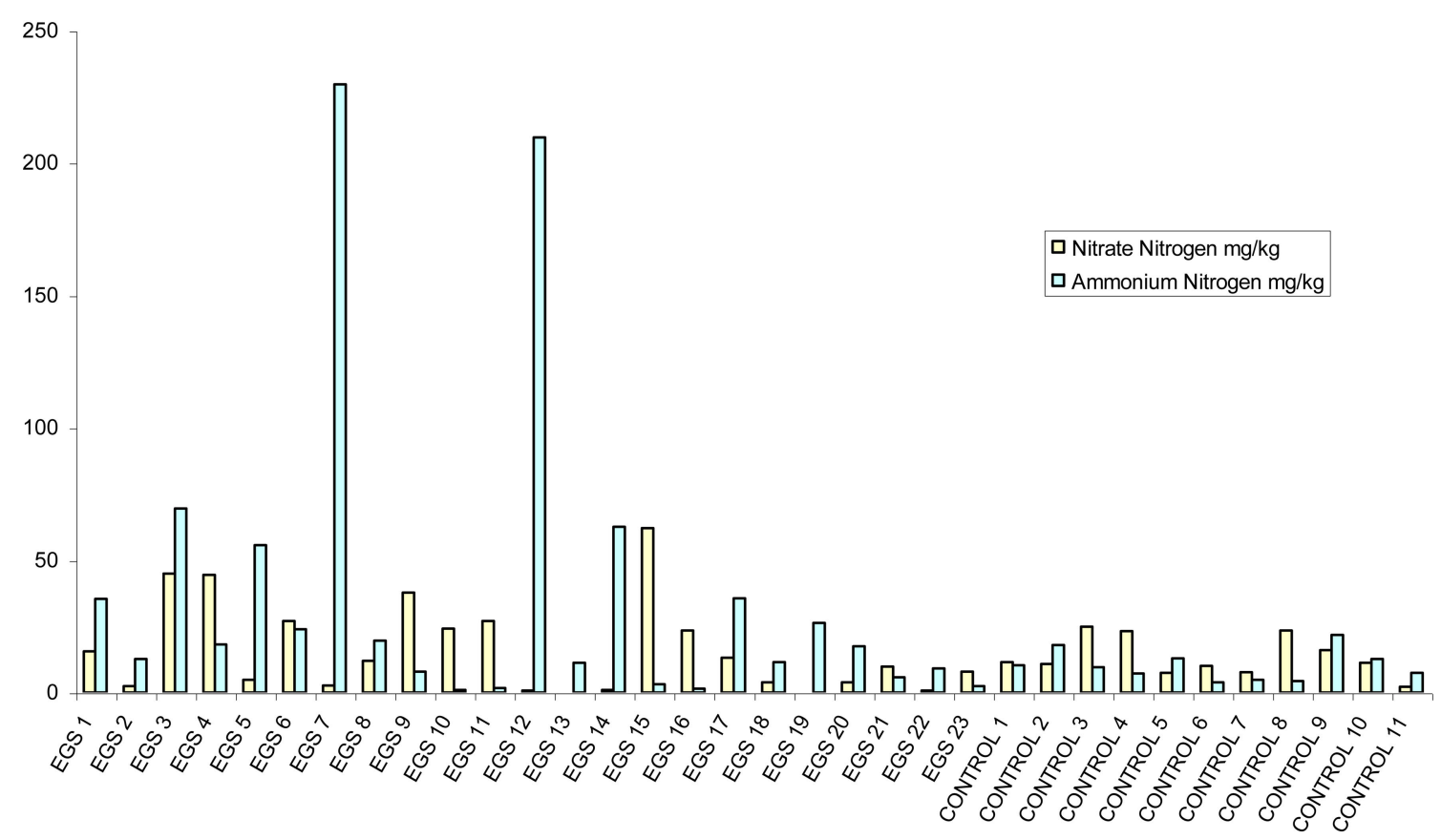

FIGURE 4 | Soil nitrogen. Soil nitrate nitrogen and ammonium nitrogen $(\mathrm{mg} / \mathrm{kg})$ per site (EGS and controls).

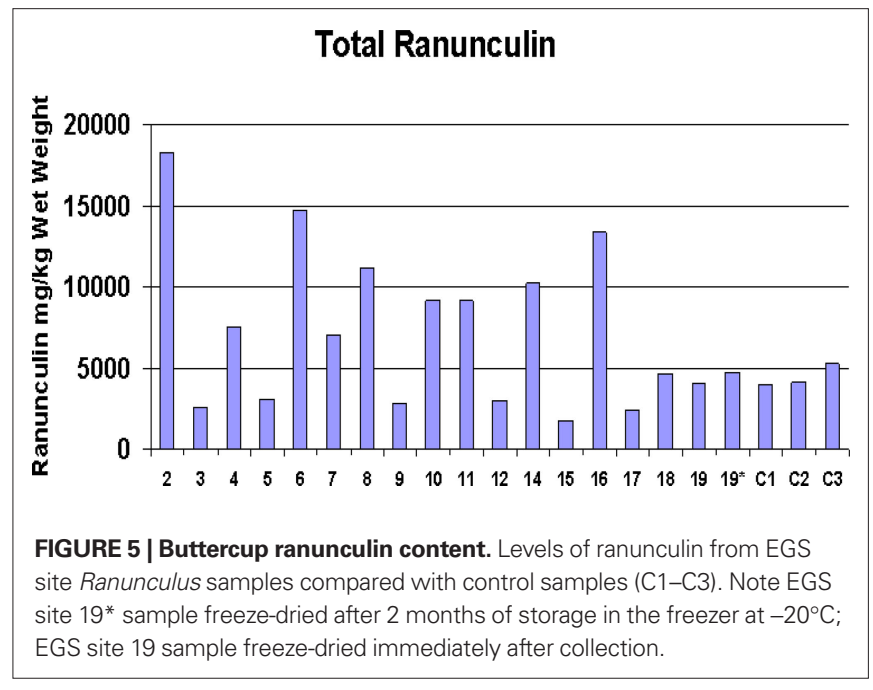

dry matter mean of $21 \%$, and total iron mean of $1818 \mathrm{mg} / \mathrm{kg}$ in EGS herbage samples, an average horse which consumes $11.5 \mathrm{~kg}$ of dry pasture per day will potentially have an intake of $100 \mathrm{~g}$ of iron per day, which is far in excess of the estimated dietary maintenance requirement for iron in a horse of $40 \mathrm{ppm}$ (Aiello, 2008). The consistently very high or excessive levels of herbage iron levels found in the EGS sites is, to our knowledge, a new, highly relevant factor in EGS etiology.

There was little difference between metal and non-metal levels in the soil samples collected from EGS and control sites. The apparent lack of association between levels of metals in soil and herbage samples can be explained partly by the fact that availability of met- als in the soil is influenced more by $\mathrm{pH}$ than total metal content. Increasing acidity results in greater release of nitrates, phosphates and heavy metals in the soil making them bioavailable to plants. Iron is more bioavailable at $\mathrm{pH} 6$ than $\mathrm{pH} 8$, since in alkaline conditions the bulk of ions are in trivalent form, but with increasing acidity a greater proportion are converted to the reduced form which is readily taken up by plants (Forbes and Watson, 1992). While no difference was seen between soil pH levels from EGS and control site samples, only six of all soil samples were neutral or alkaline. This concurs with an earlier study that found that the majority of soils from EGS sites were acidic (McCarthy et al., 2004). Other factors that influence bioaccumulation of metals include mycorrhizal fungi, and associated plant species, with some, including the grasses Agropyron repens and Lolium perenne, and white clover, Trifolium repens, known to accumulate metals in their tissues (Giasson et al., 2006; Bidar et al., 2007).

Spreading of sewage sludge (or burst sewage pipes/tanks as was the case in three of the EGS sites visited in this study), can produce mineral toxicities, as can accumulation of mine wastes (Forbes and Watson, 1992). At least two of the EGS sites were in close proximity to historic mine workings. Three other EGS sites visited were situated adjacent to busy motorways, and environmental studies have shown a correlation between number of vehicles and heavy metal concentrations in soils next to roads (Pagotto et al., 2001).

Ten of the EGS sites had soils recently disturbed (either by building-work, pipe-laying, harrowing, mole casts etc.), prior to an EGS case occurring, and soil disturbance has been highlighted as a risk factor in a previous epidemiological study, linking this with 


\section{Ranunculin $\mathrm{mg} / \mathrm{g}$ wet weight (means)}

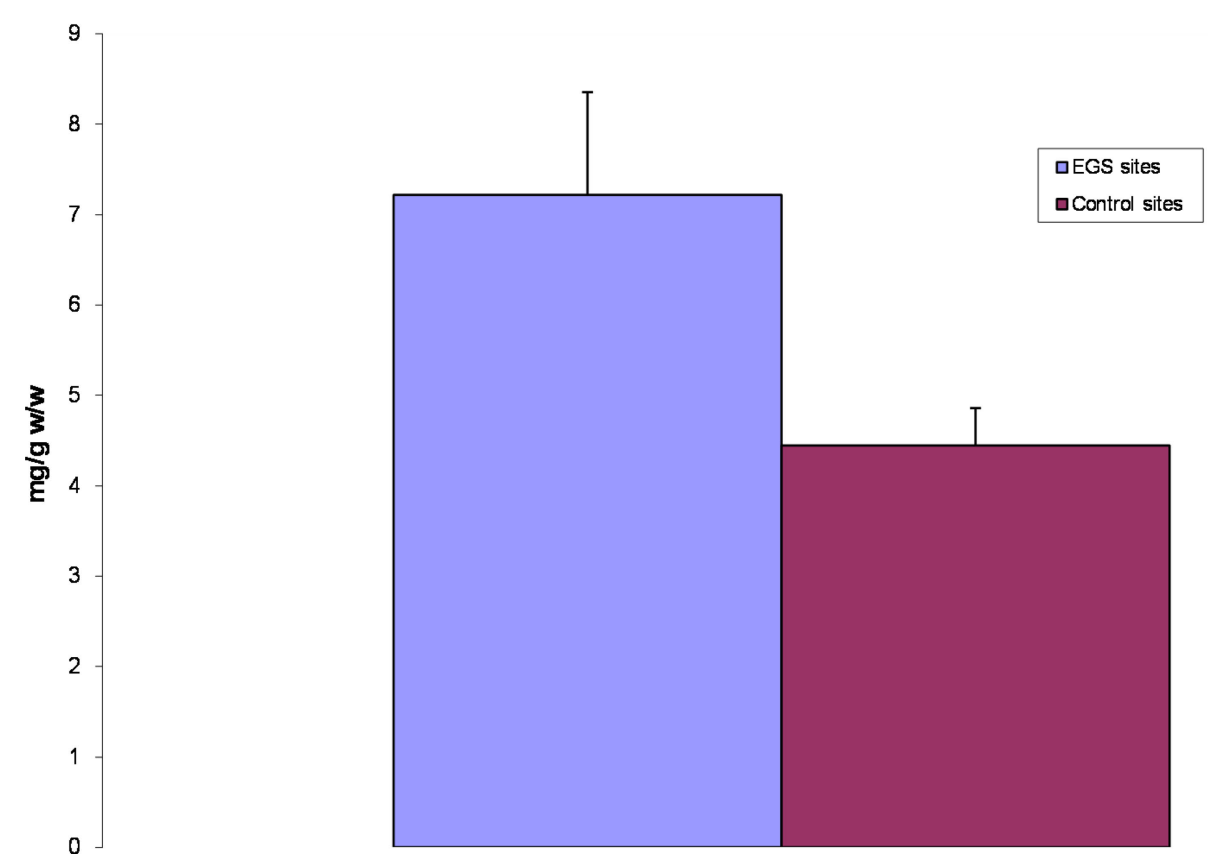

FIGURE 6 | Ranunculin levels (means). Chart showing means of ranunculin content from EGS site Ranunculus samples compared to controls. Note that ranunculin is significantly higher $(\mathrm{p}<0.05)$ in EGS site samples.

an increased rate of exposure of grazing horses to C. botulinum (Newton et al., 2004). Only 5 of the 23 EGS sites had none of these factors (i.e., notable soil disturbance, sewage spillage, or proximity to motorway/known mine workings).

Buttercups were the only toxic plant species found consistently and in abundance at each EGS site, and it is known that protoanemonin, a lactone produced after ranunculin is hydrolyzed upon mastication, is a known blistering agent and gastrointestinal irritant. Protoanemonin has also been shown to exhibit anti-bacterial and anti-fungal properties (Mares, 1987), and therefore, may impact on an equid's gastrointestinal flora. Abiotic stresses may increase protoanemonin levels in Ranunculaceae (Bonora et al., 1987). Therefore, it is possible that high levels of iron or other metals in the soil may result in higher levels of protoanemonin in Ranunculus species. However, no data are currently available on a possible correlation between available soil iron levels and levels of ranunculin, although significantly higher levels of ranunculin were found in EGS site Ranunculus samples compared to controls. As the seasonal nature of EGS corresponds with the flowering period of Ranunculus species, when the plant is more likely to have higher levels of phytoalexins, including ranunculin/ protoanemonin, further investigation into the possible role of buttercups in EGS etiology is currently being undertaken using a metabolomic approach.

It has been postulated that toxins produced by cyanobacteria, most notably MC (Mez et al., 1997) might be associated with cases of avian botulism and EGS (Murphy et al., 2000). A more recent study has shown that freshwater algae species exhibit an anticholinergic effect, which would affect the autonomic nervous sys- tem and lead to lowered gastrointestinal motility (Pérez Gutiérrez and Vargas Solís, 2007). Lack of presence of cyanobacterial toxins in EGS site water samples collected in this study indicates that a link between cyanobacteria and EGS is unlikely, and therefore can be excluded as a causative factor in EGS. Weather conditions that favor bacterial blooms and outbreaks of EGS also do not correspond.

\section{CONCLUSIONS}

In conclusion, this study has highlighted important new factors likely to be involved in EGS etiology: the significantly higher levels of iron, lead, and chromium found in herbage growing in EGS sites, in addition to toxic plant species, notably Ranunculus spp., suggest that some of the symptoms observed in EGS cases may be the result of ingestion of herbage from these sites. Based on this study, EGS appears to have a multi-causal origin, which makes it difficult to assess using standard epidemiological tools. A combination of a detailed ecological study of EGS sites with an assessment of the toxin levels in known toxic plant species clearly offers the best strategy in order to predict the risks of EGS cases occurring in areas where this disease is endemic. This study also lays the foundation for novel approaches to prevent EGS and for treating affected horses.

\section{AUTHORS CONTRIBUTIONS}

Sarah E. Edwards developed the questionnaire and database, carried out field studies, collecting soil, water, and plant samples, analyzed and interpreted the data, and drafted the manuscript. Kathrin E. Martz assisted in sample collection and undertook the investigation 
into ranunculin, and drafted the Ranunculus analysis section of the manuscript. Anja Rogge assisted in sample collection and undertook the investigation into cyanobacterial toxins in water samples, and drafted the water analysis section of the manuscript. Michael Heinrich conceived and designed the overall study, interpreted the data, and revised the manuscript.

\section{ACKNOWLEDGMENTS}

We are grateful to Mrs. Patricia Brown for a generous donation to the Centre for Pharmacognosy and Phytotherapy, School of Pharmacy, University of London which made this research possible and to Dr. Philip Brown for useful discussions. We are most grateful to all horse/pony owners \& landowners who have kindly

\section{REFERENCES}

Aiello, S. E. (ed.). (2008). The Merck Veterinary Manual [on line]. http:// www.merckvetmanual.com/mvm/ index.jsp?cfile $=\mathrm{htm} / \mathrm{bc} / 182602$.htm 2008 [consulted 15 December 2009].

Bai, Y., Benn, M. H., Majak, W., and McDiarmid, R. (1996). Extraction and HPLC determination of ranunculin in species of the buttercup family. J. Agric. Food Chem. 44, 2235-2238.

Benoni, G., Cuzzolin, L., Zambreri, D., Donini, M., Del Soldato, P., and Caramazza, I. (1993). Gastrointestinal effects of single and repeated doses of ferrous sulphate in rats. Pharmacol. Res. 27, 73-80.

Bidar, G., Garçon, G., Pruvot, C., Dewaele, D., Cazier, F., Douay, F., and Shirali, P. (2007). Behaviour of Trifolium repens and Lolium perenne growing in a heavy metal contaminated field: plant metal concentration and phytotoxicity. Environ. Pollut. 147, 546-553.

Böhnel, H., Wernery, U., and Gessler, F. (2003). Two cases of equine grass sickness with evidence for soil-borne origin involving botulinum neurotoxin. J. Vet. Med. B Infect. Dis. Vet. Public Health 50, 178-182.

Bonora, A., Tosi, B., Donini, A., Botta, B., and Bruni, A. (1987). Elicitor-induced accumulation of protoanemonin in Caltha palustris L. J. Plant Physiol. 131, 489-494.

Brej, T. (1998). Heavy metal tolerance in Agropyron repens (L.) P. Bauv. populations from the Legnica copper smelter area, Lower Silesia. Acta Soc. Bot. Pol. 67, 325-333.

Bullen, J. J., Rogers, H. J., Spalding, P. B., and Ward, C. G. (2005). Iron and Infection: the heart of the matter. FEMS Immunol. Med. Microbiol. 43, 325-330.

Carpenter,D. O. (1994). The public health significance of metal neurotoxicity. Cell. Mol. Biol. 14, 591-597.

Chorus, I., and Batram, J. (1999). Toxic Cyanobacteria in Water: a Guide to Their Public Health Consequences,
Monitoring and Management. London, England: E\&FN Spon (on behalf of WHO).

Codd, G. A., Morriso, F., and Metcalf, J. S. (2005). Cyanobacterial toxins: risk management for health protection. Toxicol. Appl. Pharmacol. 203, 264-272.

Collier, D. S, Collier, S. O., and Rossdale, P.D. (2001). Grass sickness - the same old suspects but still no convictions! Equine Vet. J. 35, 540-542.

Cooper, M, R., and Johnson, A. W. (1984). Poisonous Plants in Britain and their Effects on Animals and Man. London, England: Her Majesty's Stationery Office.

Cottrell, D. F., McGorum, B. C., and Pearson, G. T. (1999). The neurology and enterology of equine grass sickness: a review of basic mechanisms. Neurogastroenterol. Motil. 11, 79-92.

Craig, A. M., Pearson, E. G., Meyer, C., and Schmitz,J.A.(1991). Clinicopathologic studies of tansy ragwort toxicosis in ponies: sequential serum and histopathological changes. J. Equine Vet. Sci. 11, 261-262, 264-271.

De Ponti, F., D’Angelo, L., Forster, R., Einaudi, A., and Crema, A. (1991). Effect of iron succinyl-protein complexes on gastrointestinal motility in the fasting dog. Digestion 50, 72-81.

Dowler, L. E., and Siciliano, P. D. (2009). Prediction of hourly pasture dry matter intake in horses. J. Equine Vet. Sci. 29, 354-355.

Duke, J. A. (1983). Handbook of Energy Crops [on line]. http://www.hort. purdue.edu/newcrop/duke_energy// Lolium_perenne.html 1983 [consulted 24 June 2010].

EC Commission. (2006). Regulation No. 1881/2006 [on line]. http:// ec.europa.eu/food/food/chemicalsafety/contaminants/legisl_en.htm [consulted 26 July 2009]. http://eurlex.europa.eu/LexUriServ/LexUriServ. do? uri=CELEX:02006R 1881 20090701:EN:NOT.

contributed to this study. We also are grateful to the staff at NRM Laboratories who undertook analysis of soil and herbage samples. We very gratefully acknowledge the help of several colleagues for useful and important discussions about specific aspects: Dr. Andy Constanti (LSoP, pharmacology), Dr. Peter Giovannini (LSoP, EGSdistribution), Dr. Timothy Rennie (LSoP, statistics), Dr. Richard Piercy (Royal Veterinary College, EGS cases), Joyce McIntosh (EGS Fund, EGS), Dr. Judith Turner and Dr. Phil Jenning (both DEFRA, microorganisms), and Bryony Waggot (University of Edinburgh, EGS veterinary nurse). We also would like to thank Prof. em. Dr. Michael H. Benn, University of Calgary, Canada, for the ranunculin standard. The project was disseminated thanks to Horse and Hound magazine.

Edouard, N., Fleurance, G., MartinRossel, W., Duncan, P., Dulphy, J. P. Grange, S., Baumont, R., Dubroeucq, H., Pérez-Barbería, F. J., and Gordon, I. J. (2008). Voluntary intake and digestibility in horses: effect of forage quality with emphasis on individual variability. Animal 2, 1526-1533.

Evans, W. C. (1976). Bracken thiaminasemediated neurotoxic syndromes. Bot. J. Linn. Soc. 1, 113-131.

Fischer, W. J., Garthwaite, I., Miles, C. O. Ross, K. M., Aggen, J. B., Chamberlin, A. R., Towers, N. R., and Dietrich, D. R. (2001). Congener-independent immunoassay for microcystins and nodularins. Environ. Sci. Technol. 35, 4849-4856.

Forbes, J. C., and Watson, R. D. (1992). Plants in Agriculture. Cambridge: Cambridge University Press, 68-80.

French, N. P., McCarthy, H. E., Diggle, P. J., and Proudman, C. J. (2005). Clustering of equine grass sickness cases in the United Kingdom: a study considering the effect of positiondependent reporting on the spacetime K-function. Epidemiol. Infect. 133, 343-348.

Friebe, A., Schulz, M., Kück, P., and Schnabl, H. (1995). Phytotoxins from shoot extracts and root exudates of Agropyron repens seedlings. Phytochemistry 38, 1157-1159.

Garrett, L. A., Brown, R., and Poxton, I. R. (2002). A comparative study of the intestinal microbiota of healthy horses and those suffering from equine grass sickness. Vet. Microbiol. 87, 81-88.

Giasson, P., Jaouich, A., Cayer, P., Gagné, S., Moutoglis, P., and Massicotte, L. (2006). Enhanced phytoremediation: a study of mycorrhizoremediation of heavy metal-contaminated soil. Remediation 17, 97-110.

Gilmour, J. S., and Jolly, G. M. (1974). Some aspects of the epidemiology of equine grass sickness. Vet. Rec. 95, 77-80.
Götz, M. E., Künig, G., Riederer, P., and Youdim M. B. H. (1994). Oxidative stress: free radical production in neuronal degeneration. Pharmacol. Ther. $63,37-122$.

Hallberg, L., Brune, M., and Rossander, L. (1989). The role of vitamin C in iron absorption. Int. J. Vitam. Nutr. Res. Suppl. 30, 103-108.

Hilbe, M., Guscetti, S., Wunderlin, S., and Ehrensperger,F.(2005).Synaptophysin: an immunohistochemical marker for animal dysautonomias. J. Comp. Pathol. 132, 223-227.

Hsu, P. C., and Guo, Y. L. (2002). Antioxidant nutrients and lead toxicity. Toxicology 180, 33-44.

Hubbard, C. E. (1984). Grasses: A Guide to Their Structure, Identification, Uses and Distribution. London: Penguin Books Ltd.

Hudson, N., Mayhew, I., and Pearson, G. (2002). Presence of in vitro electrical activity in the ileum of horses with enteric nervous system pathology: equine dysautonomia (grass sickness).Auton. Neurosci.99, 119-126.

Hudson, N. P. H., and Pirie, R. S. (2005). Four cases of equine grass sickness: acute, subacute, chronic and surviving chronic grass sickness. Equine Vet. Educ. 17, 19-26.

Hunter, L. C., Miller, J. K., and Poxton, I. R. (1999). The association of Clostridium botulinum type $\mathrm{C}$ with equine grass sickness: a toxicoinfection? Equine Vet. J. 31, 492-499.

Järup, L. (2003). Hazards of heavy metal contamination. Br. Med. Bull. 68, 167-182.

John, H. A., Marrs, J., and Laffling, A. J. (2000). Investigation of the susceptibility of equine autonomic neuronal cell lines, clonally derived from the same paravertebral ganglion, to toxic plasma from equine dysautonomia (grass sickness) cases. Toxicol. In Vitro 14, 459-465.

Liang, J., and Karamanos, R. E. (1993). "DTPA extraction for iron," in Soil 
Sampling and Methods of Analysis, ed. M. R. Carter (Boca Raton, FL: CRC Press), 87-90.

Mares, D. (1987). Antimicrobial activity of protoanemonin, a lactone from ranunculaceous plants. Mycopathologia 98, 133-140.

Marrs, J., Small, J., Milne, E. M., and John, H. A. (2001). Liver and Biliary System Pathology in Equine Dysautonomia (Grass Sickness). J. Vet. Med. A Physiol. Pathol. Clin. Med. 48, 243-255.

McCarthy, H. E., French, N. P., Edwards, G. B., Miller, K., and Proudman, C. J. (2004). Why are certain premises at increased risk of equine grass sickness? A matched case-control study. Equine Vet. J. 36, 130-134.

McCarthy, H. E., Proudman, C. J., and French, N. P. (2001). Epidemiology of equine grass sickness: a literature review (1909-1999). Vet. Rec. 149, 293-300.

McGorum, B. C., Fry, S. C., Wallace, G., Coenen, K., Robb, J., Williamson, G., and Aruoma, O. I. (2000). Properties of herbage in relation to equine dysautonomia: biochemical composition and antioxidant and prooxidant actions. J. Agric. Food Chem. 48, 2346-2352.

McGorum, B. C., Wilson, R., Pirie, R. S., Mayhew, I. G., Kaur, H., and Aruoma, O. I. (2003). Systemic concentrations of antioxidants and biomarkers of macromolecular oxidative damage in horses with grass sickness. Equine Vet. J. 35, 121-126.

Mez, K., Beattie, K. A., Codd, G. A., Hanselmann, K.,Hauser, B., Naegeli,H., and Preisig, H. R. (1997). Identification of a microcystin in benthic cyanobacteria linked to cattle deaths on alpine pastures in Switzerland. Eur. J. Phycol. $32,111-117$.

Milne, E., and McGorum, B. (2006). Grass Sickness in Horses. http://www. grasssickness.org.uk/grass_sickness_leaflet_06.pdf 2006 [consulted 18 August 2009].

Milne, E. M., Fintl, C., Hudson, N. P. H., Pearson, G. T., Mayhew, I. G., and Hahn, C. N. (2005). Observations on the interstitial cells of Cajal and neurons in a recovered case of equine dysautonomia (grass sickness). J. Comp. Pathol. 133, 33-40.

Ministry of Agriculture, Fisheries and Food (MAFF). (1986). The Analysis of Agricultural Materials, 3rd Edn. Technical Bulletin RB427. London, UK: HMSO, 98-194.

Murphy, T., Lawson, A., Nalewajko, C., Murkin, H., Ross, L., Oguma, K., and McIntyre, T. (2000). Algal toxinsinitiators of avian botulism? Environ. Toxicol. 15, 558-567.
Nasu, T., Toda, H., and Shibata, H. (2001). Differential inhibitory mechanism of $\mathrm{Fe}^{2+}$ and $\mathrm{Fe}^{3+}$ on contraction of ileal longitudinal smooth muscle. Pharmacol. Res. 43, 95-102.

Nehru, B., and Anand, P. (2005). Oxidative damage following chronic aluminum exposure in adults and pup rat brains. J. Trace Elem. Med. Biol. 19, 203-208.

Newell, C. A., Anderson, L. A., and Phillipson, J. D. (1996). Herbal Medicines. London, England: Pharmaceutical Press.

Newton, J. R., Hedderson, E. J., Adams, V.J., McGorum, B. C., Proudman, C. J., and Wood, J.L. N. (2004). An epidemiological study of risk factors associated with the recurrence of equine grass sickness (dysautonomia) on previously affected premises. Equine Vet. J. 6, 105-112.

Nomura, M., Uehara, K., Harada, K., Uemura, E., Iga, A., Kawano, T., Nishikado, A., Saito, K., Nakaya, Y., and Ito, S. (2004). Impairment of gastrointestinal motility by nitrate administration: evaluation based on electrogastrographic changes and autonomic nerve activity. Aliment. Pharmacol. Ther. 20, 118-124.

Nunn, F. G., Pirie, R. S., McGorum, B., Werney, U., and Poxton, I. R. (2006). Comparison of IgG antibody levels to Clostridium botulinum antigens between euthanized and surviving cases of chronic grass sickness. Res. Vet. Sci. 83, 82-84.

Ochoa, R., and de Valendia, S. (1978). Equine grass sickness: serologic evidence of association with Clostridium perfringens type A enterotoxin. Am. J. Vet. Res. 39, 1049-1051.

Ochoa, R., Gomez, S., Bustos, F., and Trajos, E. (1974). Enterotoxaemia in the horse. Preliminary report on its reproduction by Clostridium perfringens toxin. Rev. Inst. Colomb. Agrop. 9, 15-49.

Paesano, R., Pietropaoli, M., Gessani, S., and Valenti, P. (2009). The influence of lactoferrin, orally administered, on systemic iron homeostasis in pregnant women suffering of iron deficiency and iron deficiency anaemia. Biochimie 91, 44-51.

Pagotto, C., Rémy, N., Legret, M., and Le Cloirec, P. (2001). Heavy metal pollution of road dust and roadside soil near a major rural highway. Environ. Technol. 22, 307-319.

Palacios, H., Iribarren, I., Olalla, M. J., and Cala, V. (2002). Lead poisoning of horses in the vicinity of a battery recycling plant. Sci. Total Environ. 290 , 81-89.

Panciera, R. J., Martin, T., Burrows, G. E., Taylor, D. S., and Rice, L. E. (1990). Acute oxalate poisoning attributable to ingestion of curly dock (Rumex cris- pus) in sheep. J. Am. Vet. Med. Assoc. 196, 1981-1984.

Pérez Gutiérrez, R. M., and Vargas Solís, R. (2007). Smooth muscle relaxing properties of the hexanic extract of freshwater algae Oscillatoria limnetica and Hydrodictyon reticulatum. Bol. Latinoam. Caribe Planta Med. Aromat. 6, 30-35.

Pirie, R. S. (2006). Grass sickness. Clin. Tech. Equine Pract. 5, 30-36.

Pool, W. A. (1928). "Grass disease" in horses. Vet. Rec. 8, 23-30.

Poxton, I. R., Hunter, L., Lough, H., and Miller, K. (1999). Is equine grass sickness (mal seco?) a form of botulism? Anaerobe 5, 291-293.

Prieto, J. M., Recio, M. C., Giner, R. M., Máñez, S., and Rios, J. L. (2003). Pharmacological approach to the pro-and anti-inflammatory effects of Ranunculus sceleratus L. J. Ethnopharmacol. 89, 131-137.

Ressler, C. (1962). Isolation and identification from common vetch of the neurotoxin $\beta$-cyano-L-anine, a possible factor in neurolathyrism. J. Biol. Chem. 237, 733-735.

Rocke, T. E. (2006). “The global importance of avian botulism," in Waterbirds Around the World, eds G. V. Boere, C. A. Galbraith, and D. A. Stroud (Edinburgh, UK: The Stationery Office), 422-426.

Rose, F. (2006). The Wild Flower Key: How to Identify Wild Plants, Trees and Shrubs in Britain and Ireland (revised edition). London, UK: Penguin Books Ltd.

Sobko, T., Reinders, C. I., Jansson, E., Norin,E., Midtvedt, T., and Lundberg, J. O. (2005). Gastrointestinal bacteria generate nitric oxide from nitrate and nitrite. Nitric Oxide 13 , 272-278.

Spoerke, D. G., and Smolinske, S.C. (1990). Toxicity of Houseplants. Boston: CRC Press, 153.

Stace, C.A. (1997). New Flora of the British Isles, 2nd Edn. Cambridge: Cambridge University Press, 1165.

Stanek, A., Gadowska-Cicha, A., Gawron, K., Wielkoszynski, T., Adamek, B., Cieslar, G., Wiczkowski,A., and Sieron, A. (2008). Role of nitric oxide in physiology and pathology of the gastrointestinal tract. Mini Rev. Med. Chem. 8, 1549-1560.

Thagard, P. (1999). How Scientists Explain Disease. Princeton, NJ: Princeton University Press, 101-117.

Tocher, J. F. (1924). Grass sickness in horses. Trans. R. Highl. Agric. Soc. Scotl. 36, 65-83.

Tocher, J. F., Brown, W., Tocher, J. W., and Buxton, J. B. (1923). "Grass sickness" investigation report. Vet. Rec. 3, 37-45, 75-89.
Uzal, F. A., and Robles, C. A. (1997). "Clinical signs of mal seco, a grass sickness-like syndrome of horses," in Proceedings of the 1st International Workshopon Grass Sickness, EMND and Related Disorders, Bern, Switzerland, 7-8.

Uzal, F. A., Robles, C. A., and Olaechea, F. V. (1992). Histopathological changes in the celiacomesenteric ganglia of horses with 'mal seco', a grass sicknesslike syndrome, in Argentina. Vet. Rec. 130, 244-246.

Valko, M., Morris, H., and Cronin, M. T. D. (2005). Metals, toxicity and oxidative Stress. Curr. Med. Chem. 12, 1161-1208.

Walker, E. M. Jr., and Walker, S. M. (2000). Effects of iron overload on the immune system. Ann. Clin. Lab. Sci. 30, 354-365.

Weinberg, E. D. (1999). Iron loading and disease surveillance. Emerg. Infect. Dis. 5, 346-352.

Weinberg,E.D. (2001). Iron, infection and sudden infant death. Med. Hypotheses $56,731-734$.

Wood, J. L. N., and McGorum, B. C. (1999). Equine dysautonomia: has grass been blamed unfairly all this time? Equine Vet. J. 31, 451-452.

Wood, J. L. N., Milne, E. M., and Doxey, D. L. (1998). A case-control study of grass sickness (equine dysautonomia) in the United Kingdom. Vet. J. 156, 7-14.

Wylie, C. E., and Proudman, C. J. (2009). Equine grass sickness: epidemiology, diagnosis, and global distribution. Vet. Clin. North Am. Equine Pract. 25, 381-399.

Conflict of Interest Statement: The authors declare that the research was conducted in the absence of any commercial or financial relationships that could be construed as a potential conflict of interest.

Received: 28 June 2010; paper pending published: 16 August 2010; accepted: 02 September 2010; published online: 25 October 2010.

Citation: Edwards SE, Martz KE, Rogge A and Heinrich M (2010) Edaphic and phytochemical factors as predictors of equine grass sickness cases in the UK. Front. Pharmacol. 1:122. doi: 10.3389/fphar.2010.00122 This article was submitted to Frontiers in Predictive Toxicity, a specialty of Frontiers in Pharmacology.

Copyright $\odot 2010$ Edwards, Martz, Rogge and Heinrich. This is an open-access article subject to an exclusive license agreement between the authors and the Frontiers Research Foundation, which permits unrestricted use, distribution, and reproduction in any medium, provided the original authors and source are credited. 


\section{SUPPLEMENTARY MATERIAL}

The Supplementary Material for this article can be found online at http://www.frontiersin.org/pharmacology/predictivetoxicity/ paper/10.3389/fphar.2010.00122/ 